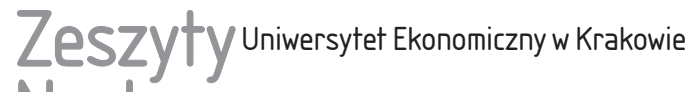 Naukowe
}

$11(947)$

ISSN 1898-6447

Zesz. Nauk. UEK, 2015; 11 (947): 5-17

DOI: 10.15678/ZNUEK.2015.0947.1101

\author{
Jolanta Kurkiewicz \\ Ewa Soja \\ Department of Statistics \\ Cracow University of Economics, Poland
}

\section{Ageing and Informal Support for the Elderly in Selected European Countries*}

\begin{abstract}
The main aim of the article is to compare the scope of the informal support that older people with difficulties in everyday life receive from outside the family in chosen European Countries. Binomial logit models were used to verify the hypothesis that receiving informal help from outside the household depends on the living arrangements and socio-economic features of those who receive the assistance. The empirical analysis draws
\end{abstract}

* The article was written for a project financed with funds allocated to the Faculty of Management of the Cracow University of Economics from a grant supporting research. This paper uses data from SHARE wave 5 release 1.0.0, as of March 31st 2015 (DOI: 10.6103/SHARE.w5.100) or SHARE wave 4 release 1.1.1, as of March 28th 2013 (DOI: 10.6103/SHARE.w4.111) or SHARE waves 1 and 2 release 2.6.0, as of November 29th 2013 (DOIs: 10.6103/SHARE.w1.260 and 10.6103/ SHARE.w2.260) or SHARELIFE release 1.0.0, as of November 24th 2010 (DOI: 10.6103/SHARE. w3.100). SHARE data collection has been funded primarily by the European Commission through the 5th Framework Programme (project QLK6-CT- 2001-00360 in the thematic programme Quality of Life), the 6th Framework Programme (projects SHARE-I3, RII-CT-2006-062193, COMPARE, CIT5- CT-2005-028857, and SHARELIFE, CIT4-CT-2006-028812) and the 7th Framework Programme (SHARE-PREP, $N^{\circ}$ 211909, SHARE-LEAP, $\mathrm{N}^{\circ} 227822$ and SHARE M4, $\mathrm{N}^{\circ} 261982$ ). Additional funding from the U.S. National Institute on Aging (U01 AG09740-13S2, P01 AG005842, P01 AG08291, P30 AG12815, R21 AG025169, Y1-AG-4553-01, IAG BSR06-11 and OGHA 04-064) and the German Ministry of Education and Research as well as from various national sources is gratefully acknowledged (see www.share-project.org for a full list of funding institutions). 
upon a new approach to population ageing presented in the Multilinks project. The results of the work allow us to demonstrate the characteristics of Central-Eastern Europe and to reveal how they differ from Northern, Western and Southern Europe. The general conclusions are compatible with results obtained by other researchers working on different databases and using different methods.

Keywords: the elderly, informal support, living arrangement, ageing.

\section{Aim of the Paper}

The aim of the article is to investigate the informal support older people who are experiencing difficulties performing activities in their daily lives receive from outside the household. Informal help in this context is personal care (e.g. help with dressing, bathing, eating, getting out of bed, using the toilet), practical household help, and help with paper work such as handling financial or legal matters ${ }^{1}$. The following hypothesis is formulated: Receiving informal help from outside the household depends on one's living arrangement and the socio-economic characteristics of those receiving the care.

The following four types of living arrangements are distinguished:

I - households composed only of persons aged 50 and over who are living alone (living alone),

II - households composed only of persons aged 50 and over who are living with a spouse/partner only (couple only),

III - households where persons aged 50 and over are living without a spouse/ partner but co-reside with children or other relatives or with unrelated people (single living with other persons),

IV - households composed only of persons aged 50 and over who are living with a spouse/partner and co-reside with children or with relatives or with unrelated people (a couple living with other persons).

Older people living alone often expect help from outside the home. This type of household is dominated by women (often widowed) and persons more advanced in age who have lost a partner, and whose children have left home. The frequency of such households is on the rise, though at the same time the opposite trend has been observed in Austria, Germany and Italy, to take three examples. In these cases, the main reasons individuals require assistance are that the mortality rate is decreasing (reducing the frequency of widowhood) and children are slower to become independent. In Central and Eastern Europe, children continue to live at home due to financial and housing difficulties (de Jong Gierveld, Dykstra

${ }^{1}$ Difficulties with activities of daily living are defined correspondingly to the concept accepted in SHARE (see http://www.share-project.org/home0.html, accessed: 15.09.2014). 
\& Schenk 2012, p. 170). Co-residing may be considered a source for all kinds of support (social, emotional, practical, financial). A prior survey found that the highest level of support is present in households shared with a partner (de Jong Gierveld, Dykstra \& Schenk 2012, p. 171).

\section{Data and Research Methods}

Data used in our research comes from the Survey of Health, Ageing and Retirement in Europe (SHARE) ${ }^{2}$. We consider the following European countries: Czech Republic, Hungary, Poland, Slovenia (Central-Eastern Europe), France, Germany (Western Europe), the Netherlands, Sweden (Northern Europe) and Portugal (Southern Europe).

In order to achieve the study's goal, logistic models are used for each country separately. The general analytical form of the logistic model is as follows:

$$
\operatorname{logit} P=a_{0}+a_{1} X_{1}+\ldots+a_{n} X_{n} .
$$

Informal help received from outside the household is applied to this model as a dependent binary variable. For a person who has received help, the variable is coded as (1), and for those who have not it is (0). Type of living arrangements is adopted as an explanatory variable. It is marked as (typhh) and is coded thus: 0 - living alone (resp. only) - ref. category; 1 - single living with other persons (resp. +); 2 - couple only (couple only); 3 - couple living with other persons (couplet).

The demographic and social-economic characteristics are taken into account as control variables. Age (age), gender (sex) and number of living children (children) are applied as demographic variables. The variable (age), measured in years, and the control variable (children) are quantitative variables. The variable (sex) is coded as 0 - male (ref. category) and 1 - female. Education level (education) and subjective evaluation of economic situation of household (sub-econ) are adopted as social-economic variables. (Education) has two categories and is coded as 0 - lower secondary at most (ref. category), 1 - at least upper secondary education. The second variable (sub-econ) has four categories: 0 - very bad (ref. category), 1 - bad, 2 - good, 3 - very good.

When adopting these variables, the applied models (1) take the following form:

$\operatorname{logit} P=a_{0}+a_{1}$ sex $+a_{2}$ sub-econ $+a_{3}$ typh $+a_{4}$ age $+a_{5}$ children $+a_{6}$ education .

${ }^{2}$ A detailed description of the source can be found on the SHARE website (http://www. share-project.org/data-access-documentation.html, accessed: 15.09.2014). 


\section{The Main Features of the Ageing Process in Chosen European Countries}

Europe is not homogenous in relation to demographic ageing. Table 1 presents the following main measures: percentage of population over 65 and over 85 years of age, ratio of population age 65 and over to $0-14$ years old.

Table 1. Ageing in Selected European Countries

\begin{tabular}{|c|c|c|c|c|c|}
\hline \multirow{4}{*}{ Country } & \multicolumn{5}{|c|}{ Measures } \\
\hline & \multicolumn{4}{|c|}{ Percentage of population aged: } & \multirow{3}{*}{$\begin{array}{c}\text { Ratio } \\
65+/ 0-14\end{array}$} \\
\hline & \multicolumn{2}{|c|}{65 and over } & \multicolumn{2}{|c|}{85 and over } & \\
\hline & Males & Females & Males & Females & \\
\hline \multicolumn{6}{|c|}{ Central-Eastern European Countries } \\
\hline Czech Republic & 16.81 & 19.51 & 1.60 & 2.26 & 113.29 \\
\hline Hungary & 17.17 & 20.63 & 1.71 & 2.40 & 118.93 \\
\hline Poland & 14.24 & 17.06 & 1.52 & 2.18 & 94.67 \\
\hline Slovenia & 17.10 & 20.24 & 1.88 & 2.83 & 118.13 \\
\hline \multicolumn{6}{|c|}{ Northern, Western and Southern European Countries } \\
\hline France & 17.57 & 19.74 & 2.79 & 3.77 & 94.65 \\
\hline Germany & 20.73 & 23.20 & 2.57 & 3.58 & 158.36 \\
\hline The Netherlands & 16.83 & 18.42 & 1.94 & 2.68 & 98.14 \\
\hline Portugal & 19.38 & 21.69 & 2.33 & 3.04 & 131.12 \\
\hline Sweden & 19.13 & 20.83 & 2.65 & 3.50 & 113.43 \\
\hline
\end{tabular}

Source: the authors' own elaboration on the basis of SHARE.

Central-Eastern European countries are less aged than other regions. Among the Northern, Western and Southern countries, Germany has the oldest population (20.73\% males and $23.20 \%$ females are aged 65 and over), while France has the highest percentage of population at age 85 (respectively $2.79 \%$ males and $3.77 \%$ females). Hungary and Slovenia have the oldest populations in Central-Eastern Europe. In Hungary $17.17 \%$ of males and $20.63 \%$ of females are age 65 and over, while their counterparts in Slovenia come in at $17.10 \%$ and $20.24 \%$, respectively. In addition, Slovenia shows the highest percentage of population at age 85 and over (1.88\% males and $2.83 \%$ females).

In developed societies with long life expectancy, one of the main determinants of population ageing, besides lower fertility, is decreasing mortality. This is espe- 
cially important in the context of increasing life expectancy at advanced ages. The data included in Table 2 allow for a comparison of life expectancy at birth $\left(e_{0}\right)$, at age 65 years $\left(e_{65}\right)$, and healthy life expectancy at age 65 years $\left(e h l_{65}\right)$ in chosen European countries.

Table 2. Life Expectancy in Chosen European Countries

\begin{tabular}{|c|c|c|c|c|c|c|}
\hline \multirow{3}{*}{ Country } & \multicolumn{6}{|c|}{ Measures } \\
\hline & \multicolumn{2}{|c|}{$e_{0}$} & \multicolumn{2}{|c|}{$e_{65}$} & \multicolumn{2}{|c|}{$e h l_{65}$} \\
\hline & Males & Females & Males & Females & Males & Females \\
\hline \multicolumn{7}{|c|}{ Central-Eastern European Countries } \\
\hline Czech Republic & 75.1 & 81.2 & 15.7 & 19.2 & 8.3 & 8.9 \\
\hline Hungary & 71.6 & 78.7 & 14.3 & 18.1 & 6.4 & 6.4 \\
\hline Poland & 72.7 & 81.1 & 15.4 & 19.9 & 7.4 & 7.8 \\
\hline Slovenia & 77.1 & 83.3 & 17.1 & 21.1 & 7.3 & 6.9 \\
\hline \multicolumn{7}{|c|}{ Northern, Western and Southern European Countries } \\
\hline France & 78.7 & 85.4 & 19.1 & 23.4 & 9.5 & 10.4 \\
\hline Germany & 78.6 & 83.3 & 18.2 & 21.2 & 6.7 & 6.9 \\
\hline Netherlands & 79.3 & 83.0 & 18.0 & 21.0 & 10.0 & 10.1 \\
\hline Portugal & 77.3 & 83.6 & 17.6 & 21.3 & 7.8 & 6.3 \\
\hline Sweden & 79.9 & 83.6 & 18.5 & 21.1 & 14.0 & 15.4 \\
\hline
\end{tabular}

Source: the authors' own elaboration on the basis of Eurostat data (http://epp.eurostat.ec.europa.eu/ portal/page/portal/statistics/search_database, accessed: 20.05.2014).

Both life expectancy at birth and at age 65 years in Germany, France, the Netherlands, Portugal and Sweden are higher than in Czech Republic, Hungary, Poland and Slovenia. The situation is less pronounced with regard to healthy life expectancy at age 65. Admittedly, the people of France, the Netherlands and Sweden enjoy the longest healthy lives, while the shortest healthy lifespan is in Hungary. Surprisingly, life expectancy at age 65 is lower in Germany than in Slovenia, Poland and Czech Republic.

There are striking differences between the European regions in amounts of social benefits old people receive (see Table 3). These benefits consist of transfers, in cash or in kind, by social protection schemes to households and individuals to relieve them of the burden of a defined set of risks or needs. The highest benefits are received in Sweden, France and the Netherlands and the lowest in Poland and Hungary. 
Table 3. Social Benefits Per Capita Given to Elderly People (in PPS)

\begin{tabular}{|c|c|}
\hline Country & Amount \\
\hline \multicolumn{2}{|c|}{ Central-Eastern European Countries } \\
\hline Czech Republic & 1866.8 \\
\hline Hungary & 1635.5 \\
\hline Poland & 1582.5 \\
\hline Slovenia & 2056.0 \\
\hline \multicolumn{2}{|c|}{ Northern, Western and Southern European Countries } \\
\hline France & 3495.9 \\
\hline Germany & 2961.1 \\
\hline Netherlands & 3466.0 \\
\hline Portugal & 2241.7 \\
\hline Sweden & 3684.2 \\
\hline
\end{tabular}

Source: the authors' own elaboration on the basis of Eurostat data (http://epp.eurostat.ec.europa.eu/ portal/page/portal/statistics/search_database, accessed: 20.05.2014).

\section{Informal Support for the Elderly with Problems with Activities of Daily Living - Results of Modelling}

The results of the logistic regression analysis are presented in Tables 4 and 5 for Central-Eastern European Countries and for Northern, Western and Southern European Countries, respectively. The models were estimated for each country separately. All models turned out statistically significant. The $a_{i}$ coefficients in model (2), for which $p$-values were smaller than 0.05 , are marked in bold italic.

Table 4. Determinants of Receiving Help from Outside the Household in Central-Eastern Europe

\begin{tabular}{|l|c|c|c|c|}
\hline \multirow{2}{*}{ Variable } & Poland & Czech Republic & Hungary & Slovenia \\
\cline { 2 - 5 } & \multicolumn{4}{|c|}{ coefficient } \\
\hline constant & $\mathbf{- 1 . 8 2 4}$ & $\mathbf{- 1 . 6 9 3}$ & $\mathbf{- 2 . 6 1 4}$ & $\mathbf{- 4 . 1 2 0}$ \\
\hline sex & -0.026 & -0.133 & -0.040 & 0.039 \\
\hline sub-econ & -0.072 & 0.007 & 0.023 & 0.007 \\
\hline typhh & $\mathbf{- 0 . 2 1 3}$ & $\mathbf{- 0 . 4 7 0}$ & $\mathbf{- 0 . 5 0 1}$ & $\mathbf{- 0 . 5 6 9}$ \\
\hline age & $\mathbf{0 . 0 2 7}$ & $\mathbf{0 . 0 3 8}$ & $\mathbf{0 . 0 4 3}$ & $\mathbf{0 . 0 3 8}$ \\
\hline
\end{tabular}


Table 4 cnt'd

\begin{tabular}{|l|c|c|c|c|}
\hline \multirow{2}{*}{ Variable } & Poland & Czech Republic & Hungary & Slovenia \\
\cline { 2 - 5 } & \multicolumn{5}{|c|}{ coefficient } \\
\hline children & -0.079 & 0.156 & 0.041 & 0.158 \\
\hline education & -0.072 & -0.028 & -0.087 & 0.173 \\
\hline \multicolumn{5}{|c|}{ Likelihood Ratio Test } \\
\hline Chi-square & 34.49 & 66.46 & 96.81 & 65.76 \\
\hline$p$-value & 0.000 & 0.000 & 0.00 & 0.000 \\
\hline
\end{tabular}

Remarks: bold italic - variable is significant $(p<0.05)$; ref. category for dependent variable: help - absence of aid; ref. category for descriptive variables: sex - male, sub-econ - very bad, typhh single only, education - at most lower secondary.

Source: the authors' own elaboration on the basis of SHARE.

Table 5. Determinants of Receiving Help from Outside the Household in Northern, Western and Southern Europe

\begin{tabular}{|l|c|c|c|c|c|}
\hline \multirow{2}{*}{ Variable } & France & Sweden & Germany & Netherlands & Portugal \\
\cline { 2 - 6 } & \multicolumn{5}{|c|}{ coefficient } \\
\hline constant & $\mathbf{- 3 . 0 5 0}$ & $\mathbf{- 2 . 3 6 9}$ & -0.847 & -1.464 & -0.141 \\
\hline sex & 0.292 & 0.137 & -0.223 & 0.314 & -0.323 \\
\hline sub-econ & -0.022 & 0.033 & 0.025 & -0.026 & -0.022 \\
\hline typhh & $\mathbf{- 0 . 3 6 3}$ & $\mathbf{- 0 . 6 1 7}$ & $\mathbf{- 0 . 2 9 7}$ & $\mathbf{- 0 . 6 3 8}$ & $\mathbf{- 0 . 6 2 9}$ \\
\hline age & $\mathbf{0 . 0 3 9}$ & $\mathbf{0 . 0 3 3}$ & $\mathbf{0 . 0 2 0}$ & $\mathbf{0 . 0 2 1}$ & 0.005 \\
\hline children & $\mathbf{0 . 1 1 4}$ & $\mathbf{0 . 1 4 9}$ & -0.035 & 0.079 & 0.017 \\
\hline education & $\mathbf{- 0 . 5 0 8}$ & -0.389 & -0.033 & $\mathbf{0 . 4 7 0}$ & -0.209 \\
\hline \multicolumn{7}{|c|}{ Likelihood Ratio Test } \\
\hline Chi-square & 90.91 & 89.75 & 20.76 & 74.00 & 39.23 \\
\hline$p$-value & 0.000 & 0.000 & 0.002 & 0.000 & 0.000 \\
\hline
\end{tabular}

Remarks: bold italic - variable is significant $(p<0.05)$; ref. category for dependent variable: help - absence of aid; ref. category for descriptive variables: sex - male, sub-econ - very bad, typhh single only, education - lower secondary at most.

Source: the authors' own elaboration on the basis of SHARE.

Odds ratios have been calculated for all statistically significant variables in the logistic models presented in Tables 4 and 5. Odds values for all the countries are displayed in Figures 1 and 2, respectively. 


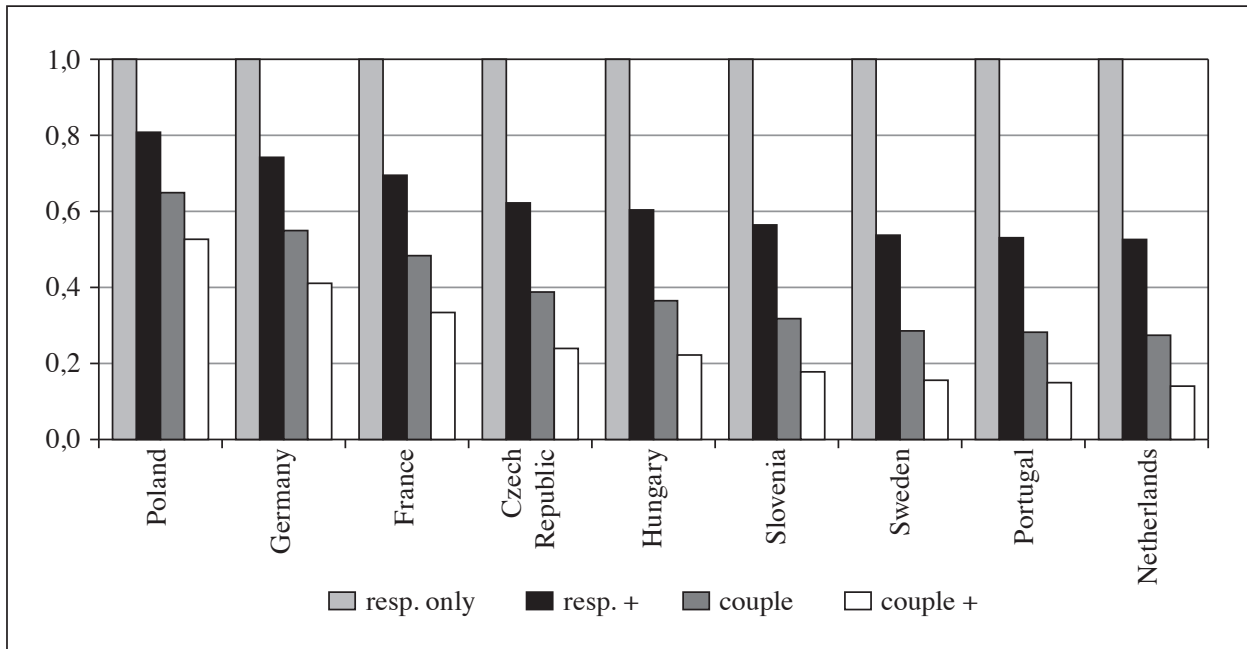

Fig. 1. Odds Ratio - Help Received from Outside the Household Variable - Type of Living Arrangement

Source: the authors' own elaboration on the basis of SHARE.

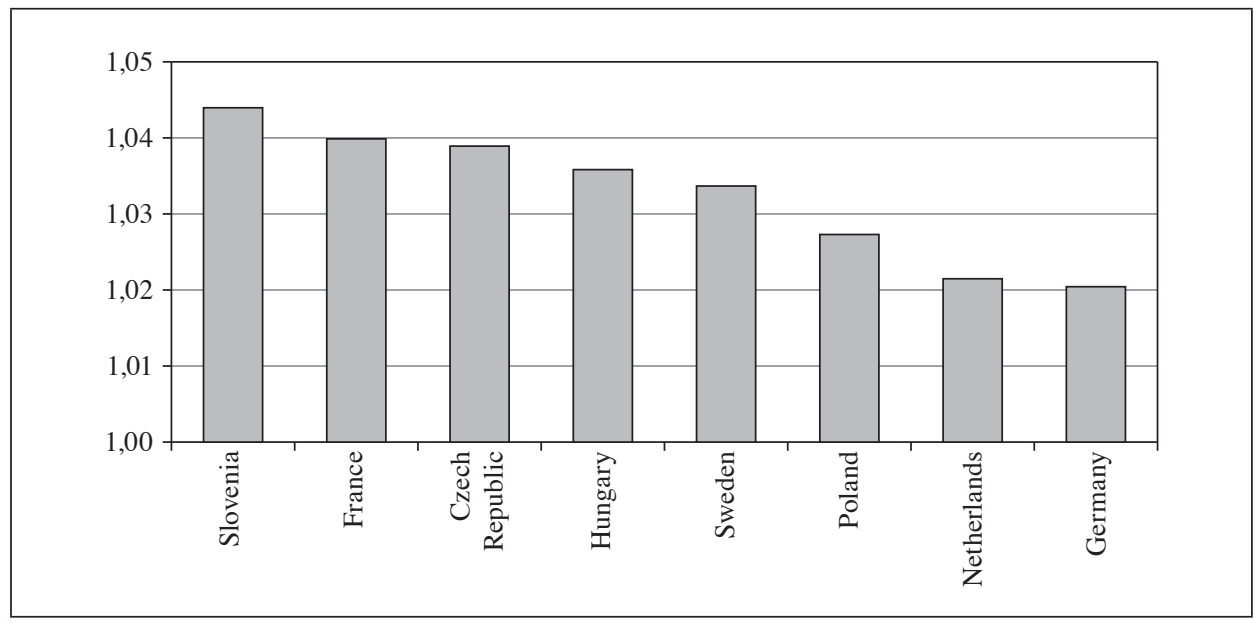

Fig. 2. Odds Ratio - Help Received from Outside the Household - Variable Age Source: the authors' own elaboration on the basis of SHARE.

A comparison of the chance of receiving informal help from outside the household with the absence of such help showed that the following variables are significant for all countries: 
1) type of living arrangements (typhh): persons who do not live alone have a lower probability of receiving informal help from outside their households than those who live alone;

2) age (with the exception of Portugal): the probability of receiving help from outside the household increases with age.

To evaluate the influence of these two variables on receiving informal help from outside the household more precisely, the odds ratios were decreased by one (in percent). They are presented in Table 6.

Table 6. Increase/Decrease in Chance of Receiving Help from Outside the Household by Significant Variables (in \%)

\begin{tabular}{|l|c|c|c|c|}
\hline \multirow{2}{*}{ Country } & \multicolumn{3}{c|}{ Typ of household } & Age \\
\cline { 2 - 5 } & \multicolumn{5}{|c|}{ resp. +} & couple & couple + & 1 year \\
\hline Czech Republic & -37.48 & -60.91 & -75.56 & 3.89 \\
\hline Hungary & -39.40 & -63.27 & -77.74 & 3.58 \\
\hline Poland & -19.21 & -34.73 & -47.27 & 2.72 \\
\hline Slovenia & -43.38 & -67.94 & -81.85 & 4.40 \\
\hline \multicolumn{5}{|c|}{ Northern, Western and Southern Europe } \\
\hline France & -30.40 & -51.60 & -66.30 & 4.00 \\
\hline Germany & -25.67 & -44.75 & -58.93 & 2.03 \\
\hline Netherlands & -47.17 & -72.09 & -85.26 & 2.15 \\
\hline Portugal & -46.71 & -71.60 & -84.87 & $-*$ \\
\hline Sweden & -46.03 & -70.87 & -84.28 & 3.36 \\
\hline
\end{tabular}

Remark: * non-significant.

Source: the authors' own elaboration on the basis of SHARE.

Reducing the chance to receive this kind of support in comparison with the households maintained by an older person living alone (resp. only) is the greatest for older people with a partner and living with other people (couple + ). The smallest decrease in the chance of receiving such help is observed for the households made up only of older persons living without a partner and co-residing with others (resp. +).

Among the countries investigated, Poland deserves our attention, as it was there that the smallest decrease in the chance of receiving help was observed for all types of households, as compared to households composed only of older person living alone (resp. only). This chance decreases respectively by $19.21 \%$ for households consisting of elderly and other persons (resp. +), by $34.73 \%$ for households created only by a couple (couple) and by $47.27 \%$ for couples living 
with others (couple + ). On the other hand, among the countries investigated, the Netherlands showed the largest decrease in the chance for informal support from outside the household. Compared to households maintained by elderly individuals living alone (resp. only), this chance is reduced by $47.17 \%$ for (resp. +) households, by $72.09 \%$ for households composed of the couple only (couple), and by $85.26 \%$ for the biggest households (couple + ). Similar results were obtained for Portugal and Sweden. Among the countries of Central and Eastern Europe, the biggest decrease in the chance to receive informal support from outside the household was observed in Slovenia. On the other hand, from the countries of Southern, Northern and Western Europe, the smallest reduction of this chance occurred in Germany.

In the light of the obtained results, it may be concluded that age is a variable whose growth entails an increase in the chance of receiving informal support from outside the household. In most of the countries from Central and Eastern Europe, the effect of age is greater than in their counterparts in Southern, Northern and Western Europe. The smallest gain in the chance of receiving help from outside of the home resulting from an increase of an older person's age by one year was observed in Germany (2.03\%), the Netherlands (2.15\%) and Poland (2.72\%). The highest increase was recorded in Slovenia (4.40\%), France (4\%) and the Czech Republic (3.89\%).

Moreover, in the case of France, the Netherlands and Sweden, besides the above-described trends, other variables were also observed to have a significant influence. They include: the level of education in France and the Netherlands, and the number of children alive in France and Sweden. In France, persons with at least secondary education have a lower chance of receiving help from outside the household, as compared to those with at most a lower secondary education. This chance is lower by $60.14 \%$. However, in the Netherlands, it is higher by $60.08 \%$. The additional living child in both France and Sweden increases the chance of getting help from outside the household by $12.07 \%$ and $16.03 \%$, respectively.

In an attempt to explain the differences between the countries of Central and Eastern Europe and those of Southern, Northern and Western Europe, we would turn back to the data on social benefits intended for the elderly in the countries considered. The highest amounts of aid per capita are transferred (in PPS) in Sweden (3684.2), France (3495.9), the Netherlands (3466), and the lowest in Poland (1582.5) and Hungary (1635.5). In countries with the highest institutional support, the chances of obtaining informal help from outside the household are smaller. 


\section{Discussion and Conclusions}

The following regularities in the domain of informal support for the elderly in chosen European Countries can be formulated:

1. In all the countries considered, only the type of living arrangements and age impact the non-institutional support received from outside the household. Larger households and younger ages decrease the chance that it will be received.

2. A higher risk of receiving informal help from a person living with other people who experience problems with everyday activities occurs more frequently in Central and Eastern Europe. Living with others facilitates the flow of informal help, which compensates for relatively low social benefits in Central-Western European countries.

3. Informal help from outside the household is directed towards elderly people at more advanced ages who live in smaller households.

A comparison of this study's results with those of others' research allows the following points to be formulated.

1. Living arrangements of people with health problems in large households are evaluated positively. The results of prior research indicate that people who have health problems and are in a difficult economic situation and have low qualifications are prone to loneliness if they live independently (Pinquart 2003, Victor et al. 2000, Hawkley et al. 2008). The frequency of living alone grows with age.

2. Similar to other researchers' findings, our study revealed that informal help from outside of the household is directed toward older people living in small households (de Jong Gierveld, Dykstra \& Schenk 2012, p. 170).

3 . The differences in the flow of support in comparable countries are consistent with others' research results. Therefore, apart from the issues already considered, cultural context and norms applying to family-related duties should be considered (Van Bavel et al. 2010).

Although it directly affects people of older age, demographic ageing should be considered in the context of the whole population. Increasing longevity is connected with an increase in the chance of survival of all phases of the demographic cycle (Lee \& Tuljapurkar) (childhood, adulthood, old age). The consequence of a decreasing level of fertility is a shrinking population of young people, who grow up among older people living longer. In a family, various kinds of interdependencies are shaped. An example includes relationships among younger and older generations, which are created by the transfer of support of various kinds. Different perspectives on the problem of ageing, including the family's, partners', children's, parents', and individuals' must be incorporated.

A new approach to demographic ageing, employing the perspective of the whole population, has been formulated by the authors of the Multilinks Frame- 
work project (How Demographic Changes... 2014). The study looked at just one kind of informal help given to older people experiencing difficulties performing activities in their daily lives. In the face of contemporary demographic changes, such help will have to be strengthened by institutional support. Care for elderly family members is provided mostly by women who are most often not mobile. These women take care of elderly parents (their own and their partners'). At the same time, their grand children may expect their help. Due to inadequate institutional support (day nurseries, kindergartens, elderly care), these women may be forced to give up their professional careers in order to take care of family members unable to live independently.

\section{Bibliography}

Hawkley L. C., Hughes M. E., Waite L. J., Masi C. M., Thisted R. A., Cacioppo J. T. (2008), From Social Structural Factors to Perceptions of Relationship Quality and Loneliness: The Chicago Health, Aging, and Social Relations Study, "Journal of Gerontology: Social Sciences", vol. 63B(6).

How Demographic Changes Shape Intergenerational Solidarity Well-being and Social Integration: A Multilinks Framework, http://www.multilinks-project.eu, accessed: 15.04.2014.

Jong Gierveld J. de, Dykstra P. A., Schenk N. (2012), Living Arrangements, Intergenerational Support Types and Older Adult Loneliness in Eastern and Western Europe, "Demographic Research, Special Collection", vol. 27(7), http://dx.doi.org/10.4054/ DemRes.2012.27.7.

Lee R., Tuljapurkar S. (undated), Death and Taxes: How Longer Life Will Affect Social Security, "004 Working Papers", University of California at Berkeley.

Pinquart M. (2003), Loneliness in Married Widowed Divorced and Never-married Older Adults, "Journal of Social and Personal Relationships", vol. 20(1), http://dx.doi. org/10.1177/02654075030201002.

Van Bavel J., Dykstra P. A., Wijckmans B., Liefbroer A. C. (2010), Demographic Change and Family Obligations, Multilinks deliverable 4.2., http://www.multilinks-project.eu/ publications, accessed: 15.04.2014.

Victor C., Scambler S., Bond J., Bowling A. (2000), Being Alone in Later Life: Loneliness, Social Isolation and Living Alone, "Reviews in Clinical Gerontology", vol. 10(4).

\section{Starzenie się ludności i pozainstytucjonalne wsparcie osób w starszym wieku w wybranych krajach europejskich} (Streszczenie)

Celem pracy jest porównanie zakresu pozainstytucjonalnego wsparcia udzielanego osobom w starszym wieku doświadczającym problemów z czynnościami życia codziennego w wybranych krajach europejskich. W celu zweryfikowania hipotezy głoszącej, że otrzymywanie pomocy pozainstytucjonalnej spoza gospodarstwa przez osoby z proble- 
mami życia codziennego jest determinowane typem gospodarstwa domowego i cechami społeczno-demograficznymi populacji otrzymującej wsparcie, skonstruowano dwumianowe modele logitowe. Teoretyczną podstawę analizy stanowi nowe podejście do starzenia się ludności przyjęte w projekcie Multilinks. Na podstawie uzyskanych rezultatów określono specyfikę krajów, które doświadczyły transformacji systemowej, oraz wskazano różnice występujące pomiędzy Europą Północną, Zachodnią, Południową i Środkowo-Wschodnią. Uzyskane wnioski są spójne z rezultatami otrzymanymi przez innych badaczy na podstawie innych baz danych i przy zastosowaniu różnych metod.

Słowa kluczowe: starsi ludzie, pozainstytucjonalna pomoc, sposób zamieszkiwania, starzenie się populacji. 